\title{
Michael Faraday en die letterlike lesing van die twee 'boeke' van God: 'n Gevallestudie oor die verhouding tussen geloof en wetenskap ${ }^{1}$
}

\author{
M. Elaine Botha \\ Departement Filosofie \\ Potchefstroomse Universiteit vir $\mathrm{CHO}$ \\ POTCHEFSTROOM
}

\begin{abstract}
The cognitive historical approach to the history of science provides a methodological approach which makes it possible to take into account most of the factors which were constitutive in the formation of scientific meaning in scientific concept formation. In this article this approach is linked with a methodology of metaphorical hermeneutics in order to determine the role played by religious factors in the meaning of scientific concepts. Contrary to traditional approaches in which religious factors are primarily seen as confessional in nature, the term religious is utilized here to identify those absolute presuppositions which fulfil a controlling or regulative function in scientific concept formation and theorizing.

This approach is applied to a case study of the relationship of faith and science in the w'ork of the nineteenth century British physicist, Michael laraday. This approach provides an analysis of the change in conceptual structure which the concept of force undergoes in a transition from a mechanisfic to a dynamistic metaphysical framework. In this analysis attention is also given to the distinction between confessional religious factors, metaphysical frameworks, meta-scientific principles and theories.
\end{abstract}

: Mct dank cn erkening aan

- Dic Sentrum vir Wetenskapsontwikkeling van dic RGN vir 'n Senior Beurs vir dic periode $1991-1993$.

- Dic Senaatskomitec vir Reformatoriese Wetenskap van dic PU vir $\mathrm{CHO}$ vir dic tockenning van ses maande vakfilosofiese verlof.

- Dic Pascal Centre for Advanced Studies in Faith and Science, Ancaster, Ont., Kanada vir 'n Navorsingsgenootskap en Studiebeurs vir ses maande in 1991. 


\section{Geloof en wetenskap: metodologiese verantwoording}

\subsection{Die konteks van ontwikkeling}

Argumente dat geloof wetenskaplike teorievorming intrinsiek beïnloed, blyk dikwels in gebreke te bly wanneer aangetoon moet word juis hoe hierdie beïnvloeding plaasvind. Dikwels redeneer diegene wat die stelling onderskryf dat sodanige beïnvloeding wel in die menswetenskapppe aantoonbaar is, maar nie so gemaklik in die natuurwetenskappe nie. Ook word geargumenteer dat dit wel moontlik is om sodanige beïnloeding aan te toon in tye waarin die wetenskap en kultuur in die teken staan van sterk godsdienstige beïnloeding soos byvoorbeeld die Middeleeue of die sewentiende eeu, maar dat in gesekulariseerde historiese periodes, die beinvloeding deur religieuse faktore eenvoudig nie in die wetenskap aantoonbaar is nie. Dikwels word religieuse beïnvloeding gesien bloot net as die aanwesigheid van religieuse of godsdienstige temata in wetenskaplike werk of wanneer religieuse of godsdienstige denkbeelde die bron of inspirasie sou wees van wetenskaplike teorieë. Wetenskaplikes ontleen dikwels die denkbeelde wat hulle wetenskaplike teorievorming stimuleer en beinvloed aan die teologie of die geloof. 'n Goeie voorbeeld hiervan is James Clerk Maxwell, die negentiendeeeuse fisikus wat die relasies van die Drie-eenheid van God en die relasie tussen die Vleesgeworde Christus en die mens as basis geneem het vir sy relasionele verstaan van die fisiese werklikheid (vgl. Torrance, 1984:215-242). Omdat relasies konstitutief is vir mens-wees en hierdie relasionele karakter van die mens afgelei is van die eenheid en relasies van die Drie-eenheid, word hierdie relasionele trek ook ingelees in die aard van materiedeeltjies en op grond hiervan ontwikkel Maxwell dan sy relasionele veldteorie. Die relasionele aard van die werklikheid blyk volgens Maxwell veral uit die analogieë wat so veelvuldig in die werklikheid voorkom. Maxwell se visie op die verhouding van teologie en ontologie is veel meer kompleks as wat hierdie enkele saak laat blyk. Hierdie metodologiese benadering, wat origens dikwels in die literatuur oor hierdie saak aangetref word, beredeneer dus die feit dat indien die wetenskaplike op een of ander wyse sy wetenskaplike teorievorining laat lei of beinvloed deur denkbeelde wat hulle oorsprong aan die Bybel, geloof of die teologie ontleen, dan sou dit blyke wees van die deurwerking van geloof in die wetenskap. Hier word die geloof, Bybel of die teologie gebruik as die bron van die wetenskaplike se wetenskaplike teorievorming oor die werklikheid. Hoewel daar in die geskiedenis van die wetenskappe talle voorbeelde is van hierdie aard (vgl. die gesaghebbende werke van Funkestein, Theology and the Scientific Imagination. From the Middle Ages to the 17th Century (1986) en Brooke se Science and Religion (1991)), het dit al gou geblyk dat godsdienstige temata of denkbeelde nie noodwendig die inhoudelike van teorievorming Christelik mak nie. Bowendien, soms berus sodanige denkbeelde op bedenklike teologie en eksegese en is 
duidelike nie-Christelike filosofiese invloede aantoonbaar. In die wetenskapshistoriese literatuur word daar tans al hoe meer aandag geskenk aan die groot verskeidenheid wyses waarop religieuse oortuigings juis wetenskaplike oortuigings beïnvloed. Martin Rudwick (1981:244,5) sê:

Among professional historians of science there is a growing awareness of the vital role that religious beliefs have played in the past in the construction of scientific world-views on both individual and collective levels. (And under 'religious beliefs' must be included in some cases strongly antireligious beliefs.) What is still more important is that these beliefs are no longer regarded as embarrassing for the reputation of a great scientist, nor are they dismissed as irrelevant to the 'real' work of science in past periods. Furthermore they are no longer treated only as 'external' factors that in particular circumstances may have retarded or advanced the intrinsic 'internal' development of valid scientific conclusions. A growing number of historians of science now routinely treat religious beliefs as a possibly constitutive factor in the formulation and acceptance not only of generalised world-views, but also of quite specific scientific theories and even of alleged observational 'facts'. Religious beliefs, in other words, are taken seriously in the task of understanding not only the context but also the content of the scientific work of past periods.

Ook ander historici van die wetenskap erken die belangrike rol wat religieuse faktore in die beoefening van die wetenskap gespeel het. So behandel Brooke (1991:16-51) onder andere die volgende relasies tussen geloof en wetenskap wat in die geskiedenis van die wetenskappe onderskei kan word:

Religieuse oortuigings as vooronderstellings van die wetenskap.

Religieuse oortuigings as sanksie vir die wetenskap.

Religieuse oortuigings as 'n motief vir die wetenskap.

Religieuse oortuigings in die selektlewe rol.

Religieuse oortuigings as regulatiewe prinsipes.

Religieuse oortuigings in 'n konstitutiewe rol in die wetenskap.

In die wetenskapsfilosofiese literatuur word oor 'n lang termyn posisies aangetref waarin reeds volop erkenning gegee word aan die rol en invloed van filosofiese en metafisiese elemente in die proses van teorievorming (vgl. onder andere Burtt, 1954:17; Agassi, 1975:208; Botha, 1986:430, ens.) maar dan word hierdie invloed dikwels beperk tot wat gangbaar genoem word die 'konteks van ontdekking' of die heuristiese fase van teorie-ontwikkeling. Hierdie posisie waarin die rol van metafisiese of filosofiese elemente in die wetenskap erken word, sou die 'swakker tese' aangaande die rol van filosofiese en metafisiese elemente in die wetenskap genoem kon word. Die 'sterker tese', naamlik dat filosofiese en/of metafisiese oortuigings in die wetenskap werksaan is, en bowendien die uitdrukking is van 'religieuse' invloed en wetenskaplike teorievorming tot op die vlak 
van begripsvorming in eksperimentele en empiriese werk sou beïnvloed, word ten spyte van die stelling van Rudwick (1981:244,5), meestal hoogs aanvegbaar geag. Die aanvegbaarheid van sodanige stelling is mede te wyte aan die meerduidige betekenis wat die begrip religieus/religie in die algemene spreektaal en die wetenskap verwerf het, asook waarskynlik hardnekkige reste van 'n positiwistiese vooroordeel teen die erkenning van die konstitutiewe rol van filosofiese vooronderstellings in die wetenskap. Dit is die bedoeling om in hierdie artikel 'n variant van die sterker tese te verdedig, een waarin naamlik geargumenteer word dat daar in die metafisiese raamwerk dikwels juis kontrole-oortuigings voorkom wat in die ontwikkeling van die wetenskaplike teorieë en die betekenisgenerering van die kernbegrippe van die teorie, 'n regulatiewe of 'religieuse' funksie vervul. Die aanvegbaarheid van die verskillende variasies op die 'sterker tese' hang ook saam met meningsverskille oor die wyse waarop betekenisvorming en referensie in wetenskaplike begripsvorming plaasvind.

Verskillende posisies word in verband met betekenisvorming in wetenskaplike begripsvorming in die literatuur aangetref: aan die een uiterste is daar die sogenaamde dubbeltaalmodel - die positiwistiese skeiding tussen teoretiese en observasietaal; aan die ander uiterste is daar variasies op die radikale betekenisvariansie-tese van Feyerabend, Kuhn c.s. waarin die teoriegeladenheid van alle waarneming en waarnemingstaal aanvaar word. Daartussen in word die netwerkteorie van betekenis verdedig waarvan Nancy Nersessian (1984a en b) onder meer ' $n$ verteenwoordiger is. Sy betoog dat juis die twee genoemde ekstreme benaderinge tot betekenisvorming en verwysing in wetenskaplike begripsvorming en betekenisvaslegging ontoereikend is om voluit die proses van betekenistoekenning in die praktyk van die wetenskap te verklaar, en suggereer dat in die plek van die twee benaderinge ' $n$ betekenisteorie gevind moet word wat rekening hou met die werklike praktyk van wetenskaplike begripsvorming. Teenoor die tradisionele onderskeid tussen die konteks van ontdekking en die konteks van regverdiging van wetenskaplike teorieë, bepleit sy 'n kognitief-historiese benadering tot die ontwikkeling van die wetenskap (1992) en stel sy - in navolging van R.E. Grandy en in onderskeiding van die kontekste van ontdekking en regverdiging - 'n 'konteks van ontwikkeling' voor (Nersessian, 1992: 6,41). Hiermee bedoel sy daardie veld van ondersoek waarin daar ondersoek gedoen word na die prosesse waardeur vae spekulasies geartikuleer word in nuwe wetenskaplike teorieë, gekommunikeer word aan ander wetenskaplikes en geleidelik die bestaande representasies van 'n bepaalde domein vervang. Die betekenisteorie wat sy voorstel (1984a en b), moet alle faktore wat ' $n$ rol speel in die vaslegging en bepaling van die betekenis van wetenskaplike begrippe in berekening bring. Dit beteken dat faktore wat op grond van ouer en ander betekenisteorieë as nie-epistemiese faktore beskou was, deur Nersessian gesien word as wesenlik bydraend tot die proses van wetenskaplike betekenisvorming en dus epistemies van aard is. Die belangrike debat tussen Nancy Nersessian en Jarret 
Leplin (1991b:678-686) oor die vraag in dié verband, word vir die doeleindes van hierdie artikel buite rekening gelaat, hoewel dit beslis as aparte diskussie belangwekkende insigte sou kon bied vir die sentrale tese wat hier verdedig word.

In aansluiting by die voorgestelde kognitief-historiese benadering van Nancy Nersessian (1987) sal in hierdie artikel aan die hand van 'n gevallestudie uit die geskiedenis van die natuurwetenskappe - die werk van die fisikus Michael Faraday - ' $n$ argument ten behoewe van die sterker tese aangevoer word. Dit sal gedoen word deur aan te toon dat wêreldbeskoulike geloofsoortuigings via kontrole-oortuigings wat werksaam is in metateoretiese raamwerke, wetenskaplike teorievorming beïnvloed tot op die vlak van wetenskaplike begripsvorming in empiriese en eksperimentele werk. Juis die funksionering van hierdie kontroleoortuigings is 'n aanduiding van 'religieuse' invloede in die wetenskap. In hierdie proses speel metafore en analogieë dikwels ' $n$ sleutelrol. Ondat die basiese metafoor wat grondliggend is aan ' $n$ metafisiese raamwerk abstraksie bemiddel, is sodanige metafoor en sy relasie tot die keuse van metafore en analogieë wat in die wetenskaplike teorie self aangetref word, dikwels 'n goeie aanduiding van die aard en tipe kontrole-oortuigings waaraan 'n voorkeurposisie toegeken word in 'n wetenskaplike navorsingstradisie of -teorie. In hierdie artikel sal beredeneer word dat juis hierdie kontrole-oortuigings die keuse van filosofiese vooronderstellings verraai wat op tipies 'wetenskaplik religieuse' wyse wetenskaplikes se werk rig en stuur. 'n Metodologie, 'metaforiese hermeneutiek', word voorgestel wat aangewend sal word om aan te toon hoe die beïnvloeding deur 'religieuse' faktore sou plaasvind Die metodologie word toegepas op enkele fasette van die ontwikkeling van die Britse negentiende-eeuse eksperimentele fisikus, Michael Faraday, se kraglyne-teorie (lines-of-force theory) wat 'n belangrike stap was in die ontwikkeling van 'n veldteorie in die fisika. Voordat egter daartoe oorgegaan word, eers enkele opmerkings oor die voorgestelde metodologie.

\subsection{Metaforiese hermeneutiek}

Die voorgestelde metaforiese hermeneuliek word aangewend ten einde die onderliggende verband tussen religieuse metafore en wetenskaplike metafore bloot te lê. Die beklemtoning van die rol van sleutelbegrippe wat in teorieë voorkom, staan sentraal in hierdie metode. Met metaforiese hermeneutiek word bedoel ' $n$ metode van interpretasie wat die metafore wat in teoretiese sisteme voorkom, identifiseer en ontleed en poog on die reikwydte van hulle betekenis te bepaal. My vooronderstelling is dat die diepste religieuse oortuigings van 'n dissipline, denker of tradisie via 'n wêreldbeskouing in sy vakwetenskaplike begrippe tot uitdrukking kom. Hierdie wêreldbeskouing is dikwels op een of ander basiese of grondmetafoor gebaseer (soos byvoorbeeld die idee dat die werklikheid 'n meganisme of 'n sisteem is). Die keuse en funksionering van die metafore en analogieë in modelle en begripsvorming gee duidelik blyke van hierdie wêreldbeskoulike 
visie wat gefundeer is in dieper religieuse oortuigings. My hipotese is dus dat die wêreldbeskouing van 'n denker, dissipline of tradisie dikwels in die keuse van 'n grondliggende (religieuse) metafoor tot uitdrukking kom en dat vakwetenskaplike begrips- en teorievorming hiervan blyke sal gee. Miskien is die eenvoudigste en beste voorbeeld die sogenaamde meganistiese wêreldvisie wat so sterk die hele gang van die natuurwetenskappe in die 17 de eeu beïnvloed het. Die hipotese dat metafore en metaforiese begripsvorming die aanknopingspunt sou wees vir die deurwerking van religieuse oortuigings in die wetenskap word gebaseer op twee belangrike sake:

* Eerstens toon die literatuur oorvloediglik aan dat metafore een van die belangrikste kognitiewe funksies in die vorming van kennis vervul en dat metafore 'n kardinale rol speel in die proses van wetenskaplike abstraksie.

* Tweedens wys die literatuur ook uitvoerig op die tipies metaforiese aard van religieuse taal en die opvallende analogieë tussen religieuse metafore en wetenskaplike metafore.

Die betekenis van wetenskaplike konsepte moet gesien word in die konteks van die netwerk van oortuigings (teoreties, metodologies, metafisies, algemene kennis) en probleme (teoreties, eksperimenteel, metafisies) wat deel uitmaak van die manier waarop wetenskaplike begrippe hulle betekenisse in die praktyk van wetenskapsbeoefening verwerf (Nersessian, 1984a:29).

\subsection{Wetenskaplike begripsvorming: die sleutel tot die deurwerking van die geloof in die wetenskap}

In die wetenskapsfilosofie van die sosiale wetenskappe en die algemene filosofie van Herman Dooyeweerd word beklemtoon dat konsepvorming die hart van wetenskaplike teorievorming uitmaak. Indien religieuse oortuigings inderdaad wetenskaplike teorievorming beïnvloed, sou wetenskaplike begripsvorming die plek wees waar dit moontlik sou moes wees om die aan- of afwesigheid van religieuse vooronderstellings te kon aantoon. As 'n mens die hoe-vraag sou wou antwoord, sou 'n mens moes kyk na die wyse waarop die betekenisinhoud van vakwetenskaplike begrippe gevorm word en funksioneer. Begripsvorming is belangrik omdat dit die wetenskaplike se metode is met behulp waarvan hy probeer om 'n teoretiese greep op die verklaring van die gedrag van die verskynsels te verkry - dit is as't ware 'n mini-instrument (soos 'n 'tregter') om iets van die wetmatighede van die werklikheid vas te vat. Hierdie vakwetenskaplike begrippe-apparaat hang dikwels ten nouste saam met die model wat deur 'n vakwetenskap(like) gekies word ten einde die werklikheid te verstaan of te verklaar. In hierdie model speel 'n grondliggende analogie dikwels 'n sleutelrol. Dink 
maar aan die analogie tussen lig en klank en golwe om 'n greep te probeer verkry op die aard van lig- en klankvibrasies.

Die boeiende van vakwetenskaplike begrippe is die feit dat hulle dikwels in verskillende wetenskappe verskillende betekenisse het en binne 'n bepaalde dissipline weer binne verskillende teorieë uiteenlopende betekenisse kan hê, maar meer nog dat dieselfde begrip in die historiese ontwikkelingsgang van 'n dissipline radikale betekeniswysiginge sou kon ondergaan. Kemmerkend van die wyse waarop vakwetenskaplikes die meersinnige betekenisse van hulle vakwetenskaplike begrippe binne die raamwerk en konteks van 'n bepaalde teorie vaslê, is die feit dat hulle ' $n$ keuse maak vir ' $n$ bepaalde analogie tussen die gedrag van verskynsels wat aan hulle bekend is en die onbekende stand van sake wat hulle graag in hulle vakwetenskappe wil verklaar. In ons alledaagse taal doen ons voortdurend ' $n$ beroep op analogieë. Dink byvoorbeeld aan metafore soos die volgende: Delarey (of is dit de Wet?) as die Leeu van Wes-Transvaal; die man is 'n wolf (die bekende metafoor/analogie wat deur Max Black $(1962,1979)$ in sy metafoorteorie gebruik is).

Max Black en Mary B. Hesse het in hulle werk die verband tussen die alledaagse verskynsel van analogie en metafore ook op die funksionering van modelle in die wetenskap van toepassing gemaak (vgl. Black, 1962, 1979; Hesse, 1966). In die wetenskap en by name in die natuurwetenskappe wemel dit van voorbeelde van sulke analogieë wat in metaforiese taal uitgedruk word en dikwels die basis vorm van 'n model wat oor 'n lang termyn navorsingsprogramme stuur, rig en lei. Bekende voorbeelde hiervan is die stelling dat lig ' $n$ golfie is of dat lig ' $n$ deeltjie is. Albei modelle wat poog om aspekte van die gedrag van lig te verhelder of te verklaar berus op analogieë. Dit is opmerklik dat juis hierdie voorbeeld een van die lastige vlieë was in die positiwistiese apteker se salf wat ten alle koste die logiese identiteitsrelasie wat die basis van objektiwiteit moes vorm, wou beskerm (vergelyk Papin, 1992). Wat het religieuse invloede en oortuigings nou met die verandering van die meersinnige betekenisse van vakwetenskaplike begrippe te make? Die antwoord op hierdie vraag verg ' $n$ nadere bespreking van die rol van religieuse kontrole-oortuigings.

\subsection{Religieuse kontrole-oortuigings}

Wat die rol en invloed van geloofsoortuigings in die wetenskap betref, is daar in wetenskaplike navorsingsprogramme, -paradigmas en -teorieë meestal 'n stel kernoortuigings aanwesig wat as stuur- (Radnitzky) of leidinggewende oortuigings (Laudan) in sodanige programme, paradigmas of teorieë optree. Wolterstorff (1984) noem hulle control beliefs. Hierdie oortuigings funksioneer dikwels op 'religieuse wyse', met ander woorde hulle duld by wyse van spreke geen teenspraak nie en word teen enige moontlike falsifiëring beskerm. Sulke kon- 
trole-oortuigings word dikwels absolute vooronderstellings genoem (Collingwood, 1940; Torrance, 1980). Sulke oortuigings mag hulle oorsprong in die teologie of godsdienstige geloofsoortuigings van 'n denker vind, maar dit is nie die bron of oorsprong van die denkbeeld of oortuiging wat die deurwerking daarvan in die wetenskap religieus maak nie, maar die wyse waarop die denker, dissipline, paradigma of navorsingsprogram hierdie oortuiging of stel oortuigings toelaat om in die proses van wetenskapsvorming te funksioneer. Die beste voorbeeld hiervan is seker die wyse waarop die Rooms-Katolieke Kerk teenoor die heliosentriese teorie van Copernikus en Galileo gereageer het. Dit is juis die grondliggende metafoor wat deur 'n denker, dissipline of teorie gekies word om as interpretasieraamwerk vir die werklikheid te dien en wat die uitdrukking is van die wêreldbeskouing van sodanige denker, dissipline of tradisie, wat dikwels dui op die tipiese stel absolute vooronderstellings wat as kontrole-oortuigings in daardie teorie diens doen. So sal 'n keuse vir die meganisme-metafoor teenoor die organismemetafoor, wanneer dit in wetenskaplike modelvorming en verklaring diens doen, duidelik sekere grense stel aan die tipe beelde en probleme wat in die wetenskaplike teorieë aan die orde gestel word. In die sisteemteorie weer, bepaal die vraag of die sisteem meganies, organies, siberneties of eko-sistemies gesien word, watter grense daar aan die interpretasieraamwerk gestel word. Die grondliggende kontrole-oortuigings van 'n dissipline, denker of tradisie word dus dikwels bepaal deur die keuse van metafoor as talige uitdrukking van ' $n$ grondliggende analogie. Die 'sterk tese', wat vervolgens verdedig sal word, stel met betrekking tot die onderlinge relasie tussen konfessionele religieuse oortuigings, metafisiese raamwerke en wetenskaplike konsepsies, dat daar binne metafisiese raamwerke bepaalde kontrole-oortuigings voorkom en funksioneer wat bowendien ook nog 'religieus' van aard sou wees en wetenskaplike teorievorming tot op die vlak van begripsvorming in eksperimentele en empiriese werk sou beïnvloed. Hierdie kontrole-oortuigings vonn deel van die stel geassosieerde gemeenplasighede wat deel uitmaak van die semantiese netwerk van 'n begrip. Ook is dit juis die betrokke element wat in die analogie en die talige verwoording daarvan in 'n metafoor as kontrole-element gekies word, wat bepaal wat die aard van die lesing van die betrokke begrip moet wees. Word die sisteemmetafoor byvoorbeeld in 'n wetenskaplike teorie geïmplementeer, dan is die keuse vir die meganiese, organiese of sibernetiese aard van die sisteemmetafoor deurslaggewend in die wyse waarop die betekenislading van die term dikwels in die konteks waarin dit voorkom, gelees moet word. 'n Keuse vir kontrole-oortuigings uit die semantiese netwerk van betekenisse van die sibernetiese metafoor impliseer dat binne die sibernetika-konteks die lesing van die model letterlik is, maar dat alle ander alternatiewe lesings van die sisteemmodel nie letterlik kan wees nie, maar juis metafories moet wees. Daar is dus 'n konteks waarbinne die sisteemmodel in enige een van die drie genoemde gestaltes letterlik gelees kan word, maar daarmee saam word dan ook die lesing in alle ander kontekste as metafories gekwalifiseer. Om hierdie stelling te illustreer en op die spoor te kom 
van die invloed van religieuse kontrole-oortuigings in die wetenskaplike werk van Michael Faraday, word begin met 'n kursoriese oorsig oor sy visie op die kragte van die natuur.

\section{Michael Faraday en die kragte van die natuur}

\subsection{Faraday se probleem}

Michael Faraday het onder andere bekendheid verwerf vir sy ontdekking van tegnieke om gasse vloeibaar te maak, bensien, elektromagnetiese induksie en die bepaling van die wette van elektrolise. Hy het ook die eerste elektriese motor en dinamo gemaak. Die fassinerende soektog wat Faraday gebring het tot die ontwikkeling van 'n natuurfilosofie en filosofie van materie wat grotendeels afgewyk het van dié van sy voorgangers, strek oor 'n leeftyd van eksperimentele werk in chemie, fisika, elektrisiteit, magnetisme en elektro-magnetisme. Sentraal in al hierdie ontdekkinge was Faraday se force-konsep wat hy juis met nuwe betekenis gevul het. Feitlik al die biograwe van Faraday stem saam dat dit juis sy religieuse en godsdienstige oortuigings was wat 'n deurslaggewende rol gespeel het in die wyse waarop hy hierdie begrip verstaan en geïnterpreteer het en wat daartoe meegewerk het dat die betekenis van die begrip krag (force) wat deur Faraday ontwikkel is, verteenwoordigend was van 'n radikale wetenskaplike omwenteling in die natuurwetenskappe.

In 1816 skryf Michael Faraday in sy Commonplace Book die volgende vrae neer: "Questions":

"Bodies do not act where they are not" Query -, is not the reverse true? Do not all bodies act where they are not; and do not any of them act where they are? (1816:324)

Hierdie probleem met betrekking tot die feit dat materie tog nie aktief kan wees waar dit self nie is nie, word reeds voor die sewentiende eeu geïdentifiseer (Hesse, 1955:337). Hoekom was dit nou eintlik 'n probleem vir Faraday? Faraday se vroegste notaboeke toon 'n preokkupasie met die verstaan van natuurkragte (forces).

* Hoe kon die aarde die maan aantrek wanneer daar duidelik niks tussen aarde en maan is wat die aantrekking kon bemiddel nie?

* Hoe kan 'n magneet 'n spyker aantrek?

* Hoekom het sommige ladinge die effek van aantrekking gehad terwyl ander weer afstoot?

Die vrae het probleme opgelewer eenvoudig omdat die gewone alledaagse ervaring van aantrekking en afstoting berus het op die ervaring van trek en stoot 
Michael Faraday en die letterlike lesing van die twee 'boeke 'van God

(push and pull). Dus was dit voor-die hand-liggend dat materie tog nie kan ageer waar dit nie was nie.

Die dominante wêreldbeskouing van die natuurwetenskaplike wêreld van sy tyd daarenteen, was nog in hoofsaak beïnvloed deur die Newtoniaanse wêreldbeeld waarin werking-op-'n-afstand (action-at-a-distance) sentraal gestaan het. Juis omdat daar by Newton elemente van sowel die meganistiese (meganiese of eterteorieë) as die dinamiese (atome met sentrale kragte) interpretasie van materie aangetref word, word hy dikwels in die geskiedenis van die natuurwetenskappe deur albei tradisies, die meganistiese en die dinamistiese, opgeëis hoewel dit duidelik is dat die dinamiese aspekte myns insiens in sy visie op materie domineer (Levere, 1971:60). Faraday het hom egter van die Newtoniaanse tradisie gedistansieer.

\subsection{Faraday en die ontwykende 'kragte' van die natuur}

Faraday het in sy visie op die materie hom van veral drie belangrike beskouinge van die Newtoniaanse tradisie gedistansieer:

* dat daar harde, ondeelbare en ondeurdringbare deeltjies sou wees;

* dat daar 'n leë ruimte tussen hierdie deeltjies sou wees; en

* dat daar sentraal-gerigte kragte sou wees wat in staat sou wees om vanaf 'n afstand op die deeltjies in te werk.

Waar baie natuurwetenskaplikes moeite gehad het met die visie van Newton - die idee van werking-op-'n-afstand, het Faraday hierdie gedagte geheel en al verwerp en dit vervang met ' $n$ opvatting oor die aard van materie wat ruimte gelaat het vir 'n veel meer dinamiese (bykans dinamistiese) opvatting van materie. Dit doen Faraday deur die invoer van sy sentrale konsep (force) krag.

Die sewentiende-eeuse idee dat materie atomisties of 'n deeltjie-karakter sou dra, is reeds in die agtiende eeu deur verskeie wetenskaplikes ernstig bevraagteken: sowel die kontakwerking van deeltjies asook die werking-op-afstand van deeltjies is deur wetenskaplikes verwerp en in die plek daarvan het variasies op die tema van die bestaan van 'n universal stuff, meestal genoem eter, met wisselende intensiteit ontwikkel. Daar was met ander woorde drie moontlike modelle beskikbaar wat diens kon doen om die werking van materie te begryp (vgl. Hesse, 1955: $338)$

* Kontak-werking (impak).

* Werking-op-'n afstand

* Werking (regstreeks of deur draaikolke) bemiddel deur een of ander medium.

Die wyse waarop hierdie probleem met betrekking tot die gedrag van materie verstaan was, was egter nog sterk gebonde aan die meganistiese interpretasie van 
materie. Dit was Faraday wat in hierdie bestaande konsepsies ' $n$ radikale wysiging gebring het en wel deur sy vernoë om met behulp van fisiese voorstellinge te probeer weergee wat werklik aan die gang was. Hy het haas geen opleiding in die wiskunde gehad nie en het ook heel weinig wiskunde ingeskakel in sy teorieë oor die werking van materie. Dit was juis hierdie pikturale representasies (pictorial representations) wat daartoe aanleiding gegee het dat hy die konsepte van kontak-werking en werking-op-'n-afstand drasties gewysig het.

Op die vraag of hierdie wysiging wat deur Faraday in die kragkonsep bewerkstellig is, iets is wat uit sy latere werk, na 1844 dateer en of dit reeds latent vanaf die begin van sy wetenskaplike werk in die kiem in sy denke anwesig sou wees, loop die meninge uiteen: Heimann (1971:237 e.v.) praat van 'n "conceptual dichotomy" in Faraday se denke tussen sy vroeere opvattinge oor "... particulate polarization, and his later work which was founded on the concept of the primacy of the lines of force". Volgens Heimann (1971) staan hier dus in die ontwikkelingsgang van Faraday se wetenskaplike werk twee visies op die aard van materie teenoor mekaar: die "particulate theory of matter" en molekulêre polarisasie teenoor die latere kraglyne-konsepsie. Heimann (1971) deel die standpunt van Mary Hesse (1961:199) dat daar eintlik in Faraday se A Speculation Touching Electric Conduction and the Nature of Matter (1844) ' $n$ oorgang is vanaf 'n meer meganistiese na 'n meer dinamiese visie. Sy (1961:201) sê:

The transition was foreshadowed by Boscovich and Kant, but Boscovich does not equate this matter with its force, and still regards his theory in terms of action at a distance, while Kant, though equating matter with repulsive force distinguishes between this, which acts by contact and attractive force which acts at a distance.

Nersessian (1984b) daarenteen is van mening dat die idee dat elektriese en magnetiese werking oor ' $\mathrm{n}$ afstand nie regstreeks plaasvind nie maar juis tyd neem, en dus ' $n$ ruimte of afstand en moontlike bemiddeling deur ' $n$ medium tussen die molekules of 'n medium veronderstel, reeds so vroeg as 1832 in Faraday se werk voorkom. Sy is dus van mening dat die veld-konsep of die alternatiewe kragteskema reeds vroeër in sy werk latent aanwesig is.

Dit was met betrekking tot elektriese induksie (geleiding) dat Faraday tot die gevolgtrekking gekom het dat die werking nie op 'n afstand plaasvind nie, maar deur 'n medium plaasvind. Die medium was egter geen materiële medium nie, maar iets anders. Sy eksperimentele werk in hierdie verband het tot konklusies gelei wat almal daarop gedui het dat daar een of ander aktiewe medium bestaan waarlangs die werking (elektrisiteit en magnetisme) gelei sou word. Deur die toedoen van Faraday is die Newtoniaanse konsepsie gewysig tot die veldkonsepsie van materie wat later deur Maxwell en in die relatiwiteitsteorie van 
Michael Faraday en die letterlike lesing van die twee 'boeke' van God

Einstein verfyn is. Volgens Cantor $(1991,1992)$ het Faraday se religieuse oortuigings in hierdie soektog 'n deurslaggewende rol gespeel.

\subsection{Faraday se veldkonsepsie}

Die voorstelling wat Faraday van hierdie 'medium' gemaak het, was die bekende (lines-of-force) kraglyne of die elektro-magnetiese veld (die patroon waarin ystervylsels val wanneer hulle in 'n magneetveld gestrooi word), maar hierdie kraglyne was nie voorgestel as materiële entiteite nie, maar as lyne wat hulle feitlik soos bondels elastiese drade gedra. Hierdie kraglyne kon

- uitsit

- buig

- in spanning verkeer

- om draaie gaan

- ineenstort

- vibreer.

Die lyn-karakter van hierdie krag verskaf die analogie op grond waarvan die gedrag van materie verduidelik en beskryf en verklaar word en dit is veral die beweging van die lyne wat van belang is. So sien Faraday dan

* statiese en dinamiese elektrisiteit as die uitsetting en ineenstorting van die lyne;

* magnetisme. lig en gravitasie as die vibrasie van die lyne en

* materie waar die lyne konvergeer.

Vir Faraday is die kragte van die natuur almal ten diepste een (want hulle reflekteer die eenheid van die onsigbare krag van God) (vgl. onder meer Cantor, 1991, 1985; Gooding, 1982, 1980; Williams, 1965 en Berkson, 1974). Ook is die kragte van die natuur nie eienskappe van materie nie; inteendeel, materie is maar net een van die talle manifestasies van die krag.

Die alternatiewe opvattings van materie in sy tyd was dié van materialisme (atome as ondeelbare deeltjies) en punt-atomisme (Boscovich): Boscovich verwys na atome as sentra van kragte. Sowel Kant as Boscovich sou materie eintlik sien as sulke 'punte' waar kragte as't ware konvergeer. Verskillende outeurs beweer dat Faraday deur hierdie denkers beïnvloed was (vgl. Spencer Brookes, 1967/68; Berkson, 1974; Jammer, 1957, Williams, 1965:78), maar hy wyk uiteindelik af selfs van die idee dat die kragte as't ware rondom punte konvergeer, om tot die konklusie te kom dat materie eintlik nie bestaan nie maar dat daar slegs kragte is. Hiervan is sy A Speculation Touching Electrical Conduction and the Nature of Matter (1844a), Matter (1844b) en On the Physical lines of Magnetic Force (1852) moontlik die beste illustrasie. Sowel Heimann (1971 as Hesse (1961) beskou hierdie geskrifte as 'n wending in Faraday se kragopvatting. Hier wys hy 
onder meer daarop dat materie slegs geken kan word op grond van sy eienskappe. Die eienskappe waaroor materie beskik, behoort daaraan op grond van die onderskeie kragte wat in en om die materie werksaam is.

* Gravitasie of gewig is herkenbaar op grond van aantrekkingskrag.

* Hardheid is kenbaar aan die krag van afstoting wat 'n objek vertoon.

* Alles wat ons van materie en sy werking weet, weet ons op grond van die effekte van die kragte werksaam daarin en die kragte is werksaam in elke klein atoom van die molekule - selfs tot in die mees miniskule puntjie.

Sy konklusie is: Waarom kan God nie net sowel sy krag rondom punte of sentra in aansyn roep as wat Hy noodwendig ' $n$ materie-nukleus eers tot stand sou bring en dit dan later met krag beklee nie? In 'n latere argumentasie (Faraday, 1844:853,854; Levere, 1968) gaan hy nog een stap verder en doen kennelik selfs afstand van die idee dat daar ' $n$ uiteindelike ' $n$ harde puntjie sou wees waaromheen die kragte groepeer. Die argument lei hom daartoe om tot die gevolgtrekking te kom dat krag die enigste fisiese substansie is. Sy krag-konsep het die onderskeid tussen materie en die ruinte tussen materie uitgeskakel, omdat dit die kragte werksaan in die ongewing van die materie asook die kragte werksaam in die materie in een konsep saamgevoeg het. Hier is nie net sprake van 'n dinamiese visie nie, maar van 'n volslae dinamisme wat waarskynlik net so aanvegbaar is as ' $n$ volslae materialisme! Van 'n standpunt dat krag een van die manifestasies van materie is, kom hy tot die posisie dat krag en materie eintlik identies is. Die vraag ontstaan nou watter rol sy geloofsoortuigings of sy wêreldbeskoulike oortuigings via 'n metafisiese raamwerk, in hierdie visie en die wysiginge wat die visie ondergaan het, gespeel het.

\section{Die verhouding van geloof en wetenskap by Michael Faraday}

\subsection{Die probleem gestel}

In die literatuur bestaan daar verskillende interpretasies met betrekking tot Faraday se natuurfilosofie, die ontwikkelingsfases wat daarin aantoonbaar is en die moontlike invloed wat sy religieuse oortuiginge daarop sou gehad het. Hoewel daar meningsverskille bestaan oor die presiese verhouding tussen sy religieuse oortuigings, metafisiese raanwerk(e), metateoretiese beginsels en fisiese teorieë, skyn daar geleidelik meer eenstemmigheid te kom dat hy eintlik in die ontwikkeling van sy visie met twee kragte-skemata gewerk het: aan die een kant 'n Newtoniaans-meganistiese kragopvatting (wat Heimann (1971) "a particulate theory of matter" noem) en aan die ander kant 'n meer dinamiese, selfs dinamistiese kragopvatting (Nersessian,1984a; Tweney, 1989a:356; Heimann, 1971: 2389; Hesse, 1961:201). Die jukstaposisie van die meganistiese visie teenoor die dinamiese visie en die benoening van eersgenoemde as Newtoniaans is eintlik onjuis omdat daar deur sowel die meganistiese as die dinamistiese tradisie op 
Newton 'n beroep gedoen word. In hierdie artikel sal daar egter tussen twee beklemtoninge in Newton se visie onderskei word en sal die Newtoniaanse visie veel sterker nog in verband gebring word met 'n partikularistiese of atomistiese filosofie van materie. Die dinamisme wat Faraday uiteindelik voorstaan, gaan veel verder as die Newtoniaanse dinamiese benadering.

Daar bestaan meningsverskil of hierdie twee kragte-opvattinge gelyktydig en vanaf die vroegste fases van Faraday se wetenskaplike werk aantoonbaar is en of die dinamistiese visie eers later al hoe sterker na vore getree het. Ook oor die moontlike rol wat sy Sandemanian geloofsoortuigings in sy wetenskaplike werk gespeel het, bestaan daar meningsverskil: hierdie meningsverskil strek van standpunte wat beweer dat hy 'n sterk skeiding tussen geloof en wetenskap sou voorgestaan het, en waarvoor daar 'n enkele sitaat in sy werk te vinde is, tot andere wat meen dat sy religieuse oortuiginge sy werk tot in die fynste detail beïnvloed het. Cantor (1991; 1992) byvoorbeeld, argumenteer dat Faraday se religieuse oortuigings die metafisiese raamwerk van sy wetenskaplike werk bepaal het. Hierin het sy fundamentalistiese benadering tot die letterlike lees van die Skrif en sy empiristiese epistemologie met die eis van die uitskakeling van alle spekulasie en vooroordeel - die letterlike 'lees' van die natuur - 'n deurslaggewende rol gespeel. Tussen die twee standpunte is daar 'n standpunt soos dié van Heimann $(1971: 245)$ wat beweer dat hoewel Faraday se religieuse oortuigings algemene stellings bevat oor God se almag en die goddelike orde, dit nogtans nie sy aanvaarding van enige spesifieke opvatting of teorie oor die aard van materie beïnvloed het nie. Omdat die onlangse werk van Geoffrey Cantor oor Michael Faraday heelwat lig werp op die onderlinge simbiotiese verhouding van geloof, metafisika, metateoretiese beginsels en wetenskaplike teorieë, word dit as aanknopingspunt gebruik vir die argument wat hier verdedig word. Die argument wat egter in hierdie artikel ontwikkel word, wil die bemiddeling van die sogenaamde 'religieuse' invloede anders as in die Cantor-hipotese konstrueer, naamlik via die invloed van religieuse kontrole-oortuigings wat veral merkbaar word in die beklemtoning van sekere fasette in die semantiese fokus van die analogieë wat deur Faraday gebruik word in sy twee kragte-skemata. Vervolgens word kortliks stilgestaan by die Cantor-hipotese

\subsection{Faraday se religieuse oortuigings: die Cantor-tese}

In onlangse werk gee die bekende wetenskapsfilosoof en -historikus, Geoffrey Cantor van Leeds, in sy boek Michael Faraday, Sandemanian and Scientist (1991), 'n boeiende biografiese uiteensetting van die belangrike werk van Michael Faraday en wy hy veral aandag aan die verband tussen sy religieuse oortuigings, metafisiese raamwerk, metateoretiese stellings en sy wetenskaplike ontdekkings en teorieë. In Cantor se lesing Interpreting Michael Faraday as the (hristian Philosopher: The Problem of Metaphysics (1992), brei hy uit op die probleem 
M. Elaine Botha

van die verhouding tussen geloof en wetenskap in die algemeen, en in die besonder by Faraday. Cantor toon aan dat daar tussen Faraday se religieuse, metafisiese en wetenskaplike insigte 'n simbiotiese verhouding bestaan het. Die religieuse oortuigings van Faraday wat in sy 'teologie van die natuur' tot uitdrukking gekom het, beïnvloed sy wetenskaplike werk via die bemiddeling van 'n aantal metawetenskaplike prinsipes. Faraday het geglo in die goddelike ekonomie van die natuur - 'n metafisiese oortuiging wat op sigself ontoereikend was om sy fisiese teorieë te artikuleer. Verdere metafisiese oortuigings by Faraday sou die volgende insluit:

* Die natuur is God se skepping.

* Die Skrif is ontwyfelbaar (letterlik) waar

* Die onsigbare 'krag' van God onderhou alle kragte van die werklikheid. Alle natuurkragte is die uitdrukking van hierdie onsigbare krag van God.

Hy het egter, so redeneer Cantor (1992:6), "... proceeded to draw from it several cashable metascientific principles ...". Hieronder was daar byvoorbeeld beginsels soos:

* Die eenheid en eenvoud van die natuur.

* Die letterlike (fisiese) verstaan van die krag van God.

* Fisiese krag word gekonserveer of bewaar en is onvernietigbaar.

* Direkte proporsionaliteit (wat sterk gefigureer het in elektro-chemiese en elektriese ondersoeke).

* Die wetmatigheid van die natuur, die konservering en korrelasie van kragte.

* Die beginsel van plenitude en die ekonomiese distribusie van die kragtelyne (vgl. ook Cantor, 1991: 168-174).

Cantor wys ook daarop dat daar in die werk van Faraday talle sitate voorkom waarin die stelling oor die verband tussen sy religieuse en natuurwetenskaplike oortuigings en taalgebruik duidelik geillustreer word. Moontlik is die volgende aanhaling een van die mees tekenende:

And when we ... perceive that all this is done by virtue of powers in the molecules which are indestructible, and by ways of action the most simple and unchangeable, we may well, if I may say it without irreverence, join awe and rembling with joy and gladness.

Our philosophy, feeble as it is, gives us to see in every particle of matter, a centre of force reaching to an infinite distance: binding worlds and suns together, and unchangeable in its permanency. Around this same particle we see grouped the powers of the various phenomena of nature: ... the harmonious working of all these forces in nature, until at last the molecule rises 
Michael Faraday en die letterlike lesing van die twee 'boeke ' van God

up in accordance with the mighty purpose ordained for it, and plays its part in the gift of life itself. And therefore our philosophy, whilst it shows us these things, should lead us to think of Him who hath wrought them; for it is said by an authority far above even that which these works present, that the invisible things of Him from the creation of the world are clearly seen, being understood by the things that are made, even His eternal power and Godhead. (Aangehaal deur Levere, 1971:76,7 verwysend na: Faraday, M. Royal. Instit. MS 23. In: Bence-Jones, The Life and Letters of Faraday, (3), vol. $2,229,30$.)

In die sitaat blyk dit dat daar vir Faraday tussen die krag (power) van God en die kragte van die natuur ' $n$ besonder noue korrelasie bestaan (Cantor, 1992:6). Juis hierdie religieuse krag-konsep en sy besondere interpretasie van Romeine 1:20 het dan ook, aldus Cantor, 'n beslissende invloed gehad op die wyse waarop Faraday sy fisiese kragkonsepte ontwikkel het. Laat ons egter die Cantorhipotese van naderby bekyk.

Faraday was lidmaat van die Sandemanians, 'n sektegroepering wat van die Church of Scotland weggebreek het omdat dit radikaal van die staatskerk verskil het oor die Bybelse fundering vir die bestaansreg van 'n 'nasionale' kerk. Die Sandemanians het nie die laaste deel van die sitaat in Romeine 1:20 geïnterpreteer soos in die natuurlike teologie nie, dit wil sê dat die mens vanaf 'n kennis van die natuur na God toe sou kon opklim nie. Nee, inteendeel. Juis die kennis van God sou die mens in staat stel om die natuur te verstaan. Levere (1971: 78.9) stel dit so:

.. he adopted a theology of nature, rather than natural theology. This
inability of man to find God by "reasoning from the things of this life' also
comes to the fore at the commencement of his lecture "On mental
education" in 1854 (Faraday, $\mathrm{M}$. 1859 . (1991). Experimental Researches in
Chemistry and Physics, 464 ). Faraday says: "Let no one suppose for a
moment that the self-education I am about to commend in respect of the
things of this life, extends to any considerations of the hope set before us, as
if man by reasoning could find out (jod." (MEB)

Die verwysing na Romeine 1:20 kom herhaalde kere in Faraday se geskrifte voor en het volgens Cantor as 'n sentrale religieuse leidraad gedien wat die hele metafisiese raamwerk van sy wetenskaplike werk gedra het. 'n Belangrike trek van hierdie metafisiese raamwerk was, volgens Cantor, die strukturele ooreenkoms wat Faraday tussen die "spiritual and moral universes ..." (Cantor, 1991) gesien het. Vir Faraday kon hierdie uitdrukking 'die krag van God' eenvoudig nie metafories begryp word nie, want God het Hom nie op ' $n$ geheimsinnige en metaforiese wyse aan die mens geopenbaar nie en bowendien spreek God letterlik en nie in metaforiese taal nie - so sou Faraday redeneer. Krag was vir Faraday "... the very stuff of the physical world" (Cantor, 1991: 175). Elke deeltjie van die 
werklikheid was ' $n$ manifestasie van die krag van God en hierdie krag het tot uitdrukking gekom in hitte, elektrisiteit, magnetisme, gravitasie, chemiese affiniteit, ensovoorts. Vir Faraday was egter juis elektrisiteit die hoogste van al God se kragte van die natuur. Vir Faraday, die navolger van Sandeman, loop die drade van die krag van God deur alle aspekte van die menslike lewe en deur die fisiese wêreld wat deur God geskep is. Hy verwerp dus die beeld van die natuurlike teologie waar God gesien word as 'n vaardige ambagsman of kunstenaar. In plaas daarvan om soos 'n kunstenaar die werklikheid kunstig te vorm, het God deur 'n woord die werklikheid in ansyn geroep. Faraday het geredeneer dat dit nie moontlik is om die oorsprong van die kragte van die natuur te peil nie en ook nie moontlik is om te weet hoe hierdie kragte in materie verenig is nie - dit weet God alleen. Al wat die mens kan weet, is die effek of uitwerking van hierdie krag, die relasies tussen die kragte en die wette wat hierdie werking reguleer. Hy redeneer dus soos volg: God het by die skepping 'n perfekte sisteem tot stand gebring waarin daar geen verlies van krag kan plaasvind as gevolg van fisiese prosesse nie. Die totale hoeveelheid $\mathrm{krag}$ in die heelal bly behoue en kan nie vernietig word of opnuut geskep word nie. Die mens het egter geen toegang tot die absolute krag (parent force) in die heelal nie (Cantor, 1991:185). Al wat ons kan ken, is die waarneembare kragte van die natuur soos hitte en elektrisiteit. Slegs God kan krag skep of vemietig. Op die agtergrond van die waarneembare verskynsels moes 'krag' as 'n abstrakte entiteit agter die individuele manifestasies van krag bestaan het, maar die mens het geen toegang daartoe gehad nie. Faraday sê:

... we know nothing of [the] origin of powers or how they are united with matter, we are outside the legitimate bounds of science if we try to specify power or force as an abstract entity. Since all powers in the physical universe are manifested by God, speculations on the nature of force may be encroaching into the area of theologically dangerous hypotheses. Put simply, while correlation concerned the relation between observables, conservation was a metaphysically charged term (Cantor, 1991:187).

Terloops, moontlik toon hierdie sitaat die beste aan dat vir Faraday hierdie metafisiese beginsel dat krag nie geskep of vernietig kon word nie, as kontroleoortuiging in die ontwikkeling en uitbou van sy wetenskaplike teorie gedien het. Cantor (1991: 192-193) redeneer dat sowel Joule as Faraday ' $n$ teologie van die natuur aangehang het wat daarvan uitgegaan het dat dit absurd sou wees om te dink dat die kragte wat God in die materie geplaas het, enigsins vernietig kan word of geskep kan word deur die skeppende krag van die mens. Cantor (1991: 193) stel dit soos volg:

... such a belief in the 'economy of nature' was subject to a number of different and even incompatible interpretations. For example, Joule and Thomson who subscribed to latitudinarian principles and to natural 
theology, envisaged their God conserving the mechanical operations of nature in accordance with the principle of conservation of work and 'vis viva' (living force). Joule could speak of 'the wisdom and beneficence of the Great Architect of nature' and of 'the entire machinery' of the universe working 'smoothly and harmoniously' - terms from natural theology that connote God as the Designer of a mechanical universe. By contrast the Sandemanian, Faraday interpreted the Bible in a more literal manner and portrayed the God of Genesis as the source of power, which is conserved. The powers we observe in matter are ultimately derived from that power but they are not reducible to mathematics or mechanics. Faraday's God was no artificer or engineer.

Hierdie krag wat God by die skepping van die wêreld in die werklikheid geplaas het, bly bewaar. Faraday praat dus van 'n Goddelike ekonomie van die natuur (the Divine economy of nature) wat tot uitdrukking kom in die onvernietigbaarheid en konservering van krag - maar, nie van energie nie. Sy opvatting van krag het hom daarvan weerhou om die latere meganiese konsepte van krag, werk en energie wat deur die energie-fisika van Joule, Thomson en ander ontwikkel is te aanvaar. Sy opvatting van kragkonservering is dus nie dié van energiekonservering nie (die eerste wet van die termo-dinamika). Joule en ander het onder meer geredeneer dat hitte in krag omgesit kon word en krag in hitte omgesit sou kon word, maar Faraday het dit gesien as in stryd met sy diepste religieuse en metafisiese oortuiging dat beweging (motion) nie een van die eienskappe van materie was nie. Hitte, wat die gevolg is van die beweging van materiële deeltjies, sou dus in beweging tot uitdrukking kon kom, maar hitte was nie beweging nie; hitte is ' $n$ manifestasie van krag. Bowendien, so 'n teorie sou aan gewone fisiese verskynsel die vermoë toeken om krag te 'skep' en die voorreg kom slegs God toe. Cantor (1991) wys daarop dat twee sake in Faraday se wetenskaplike werk 'n deurslaggewende rol speel:

* Sy letterlike hermeneutiek van die Skrif, wat die voorskrif was van sy kerkgroepering en

* sy empiristiese epistemologie waarin hy redeneer dat net soos die Skrif sonder enige vooroordeel of hipotese of eie uitleg gelees mag word, dus letterlik verstaan moet word, God se openbaring in die natuur op dieselfde wyse, dit wil sê letterlik verstaan moes word.

Die Cantor-hipotese is besonder verhelderend oor die wyse waarop konfessioneel religieuse oortuigings via die bemiddeling van 'n metafisiese raamwerk met duidelike metateoretiese aannames Faraday se kragopvatting beïnvloed het. Tog stel dit die sterker tese voor bepaalde probleme: die grondliggende religieuse oortuiging van Faraday het in beginsel blykbaar twee kragteskemata en moontlik selfs twee metafisiese raamwerke in sy denke toegelaat. Hier word nou verwys na die meganistiese en die dinamistiese aksente in sy kragopvatting. 


\subsection{Een stel konfessionele religieuse oortuigings, twee metafisiese raamwerke en twee kragteskemata?}

Indien 'n religieuse raamwerk twee metafisiese raamwerke toelaat sou die vraag kon ontstaan na die aard van die wisselwerking tussen die religieuse oortuigings en die onderskeie metafisiese raamwerke. Dit is moontlik dat dit juis Faraday se Sandemanian godsdienstige oortuigings was wat hom in die rigting van die dinamistiese natuurfilosofie gestuur het. Die literatuur toon egter oorvloediglik aan dat hierdie fundamentalistiese religieuse oortuigings vanaf die begin in sy lewe en wetenskaplike werk gefunksioneer het, dit wil sê in 'n fase waarin hy die meer partikularistiese materieteorie aangehang het. Dit sou dus nie slegs vir ' $n$ moontlike latere ontwikkeling in sy wetenskaplike werk verantwoordelik gehou kon word nie. Andersyds sou daar ook, soos Nersessian (1984a) dit doen, geredeneer kon word dat die dinamistiese kragkonsep wat grens aan die latere veldkonsepsie, eintlik latent en implisiet vanaf die begin in sy werk aanwesig was. Die implikasie hiervan sou wees dat sy konfessionele religieuse oortuigings vanaf die begin van sy werk die aanwesigheid vall twee metafisiese raamwerke toegelaat het, die meganistiese en later die dinamistiese een.

Die Cantor-tese bied ' $n$ verklaring vir die feit dat Faraday die kragbegrip letterlik geîmplementeer het, maar dit verklaar nog nie die oorgang van die meer meganisties-georiënteerde kragteskema na die dinamistiese kragteskema nie en nog minder die verskil in letterlike lesing en betekenisinhoud tussen die twee konnotasies van die kragte-skemata wat hy geleidelik begin implementeer het. In werklikheid het een oorkoepelende sentrale konfessionele religieuse oortuiging die letterlike interpretasie van twee verskillende kragteskemata gesanksioneer. Indien die stelling waar sou wees, stel dit die sterk tese, hierbo genoem, voor bepaalde probleme. Meer nog, die relasie tussen religieuse oortuiging, metafisiese raamwerk en wetenskaplike teorie wat sowel deur Cantor asook deur hierdie studie verdedig word, vra dan on verdere toeligting. Die vraag ontstaan of dit nog moontlik is te argumenteer dat die invloed van 'religieuse faktore' in sy wetenskaplike werk werksaam is, wanneer een stel konfessionele oortuigings oënskynlik twee metafisiese raamwerke en twee kragteskemata sanksioneer. Dit is duidelik dat die historiese toedrag van sake by Faraday, soos onder andere aangetoon deur Cantor $(1991,1992)$ ' $n$ argument ten behoewe van die reglynige kousale verband tussen konfessionele en religieuse oortuigings aan die een kant en metafisiese raamwerke aan die ander kant, deursny. Cantor self ag dit nodig om tussen hierdie twee groothede metawetenskaplike bemiddelende prinsipes te postuleer. Maar meer nog: oënskynlik trek dit ook 'n streep deur 'n reglynige relasie tussen metafisiese raamwerke en wetenskaplike teorieè. Dit is duidelik dat die Cantor-tese asook 'n algemene stelling dat religieuse oortuigings in die sin van konfessionele religieuse oortuigings die wetenskap konstitutief sou beïnvloed,

Koers 58(2) 1993:1+1-167 
ons voor probleme stel. Hierdie probleme kom na vore wanneer dit blyk dat een stel konfessionele oortuigings hetsy meerdere metafisiese raamwerke of meerdere kragteskemata sanksioneer. Dié toedrag van sake bly onverminderd problematies wanneer daar hipoteties afgesien word van die moontlike invloed van konfessioneel religieuse oortuigings en slegs die invloed van metafisiese raamwerke soos byvoorbeeld die moontlike invloed van Kant of die Duitse Naturphilosophie in berekening gebring word.

Ten opsigte van die invloed van die letterlike lesing van die Skrif en die natuur ontstaan die vraag: wat was eerste? Het die letterlike lesing van die natuur wat 'n oorspanning van die 'krag'-metafoor in sy eksperimentele werk met fisiese verskynsels tot gevolg gehad het, aanleiding gegee tot 'n dinamistiese verstaan van 'krag' in die Skrif (Rom. 1:20) en hom die Bybelse (metafoor) begrip 'die krag van God' letterlik laat lees en verstaan, of was dit die letterlike verstaan van die Bybelgedeeltes wat hom beïnloed het in sy dinamistiese verstaan van die natuur? Wat beteken dit om te sê dat Faraday sowel die Bybel as die natuur letterlik wou interpreteer? Dit is duidelik dat die interpretasie van die tweedeling en teenstelling tussen 'letterlik' en 'metafories' hier om verheldering vra en dat die verskuiwing in die metafisiese raamwerk en die verhouding van hierdie verskuiwinge tot sy religieuse oortuiginge verklaring verg. Hierdie probleme vra om die oorweging van 'n alternatiewe hipotese vir die verklaring van die verhouding tussen geloof en wetenskap by Faraday. In sodanige hipotese sal die aard en rol van 'n (konfessioneel) religieuse oortuiging en die verhouding daarvan tot ' $n$ metafisiese raamwerk enersyds en 'n substantiewe teorie andersyds aandag moet geniet. Daar is egter ook ander vrae wat aandag moet geniet - vrae soos die volgende: Op watter punt word die kragbegrip meganisties-letterlik gelees en op watter punt dinamisties-letterlik? Wat sou 'n metaforiese lesing van die konnotasies van enige een van die twee begrippe konstitueer? Een element van die Cantor-tese bied vir 'n altematiewe hipotese ' $n$ belangrike aanknopingspunt en dit is die stelling dat dit juis die letterlike lesing van sowel die Skriftuur en die natuur was wat Faraday gebring het tot die besondere betekenislading van sy kragkonsep. Laat ons hierdie element in die lig van die voorgestelde metaforiese hermeneutiek 'n bietjie verder ontleed.

\subsection{Die krag-metafoor: twee letterlike lesings?}

Waar Cantor redeneer dat Faraday se sogenaamde teologie van die natuur hom voorsien van 'n stel metawetenskaplike beginsels wat sy keuse van 'n partikularistiese materie-teorie determineer, blyk dit dat Faraday se konfessionele religieuse oortuigings eintlik twee verskillende stelle metawetenskaplike of wêreldbeskoulike oortuigings sanksioneer, te wete aanvanklik 'n oorwegend partikularistiese materie-teorie wat later vervang word met 'n oorwegend dinamistiese opvatting van materie. Die verskuiwing en oorgang van die een teorie na die ander 
hang saam met die invoer van 'n nuwe metaforiese voorstelling van krag wat veel sterker in die teken staan van 'n dinamistiese lesing van die natuur. Hierdie tendens kom sterker na vore in sy sogenaande tweede kragteskema. Juis die wyse waarop Faraday die metaforiese voorstelling van kraglyne dinamisties inklee, verraai die deurwerking van dieperliggende metafisiese oortuigings. In hierdie metafisiese oortuigings speel bepaalde fokuspunte vall die onderliggende analogie wat in sy pikturale voorstelling van kraglyne voorkom, 'n deurslaggewende rol. Daar sou gestel kon word dat juis hierdie fokuspunte die rol van religieuse kontrole-oortuiging vervul. Wat is hierdie fokuspunte? Dit word vervolgens met behulp van die skematiese voorstelling van die twee kragteskemata voorgestel:

\section{Kragteskema I}

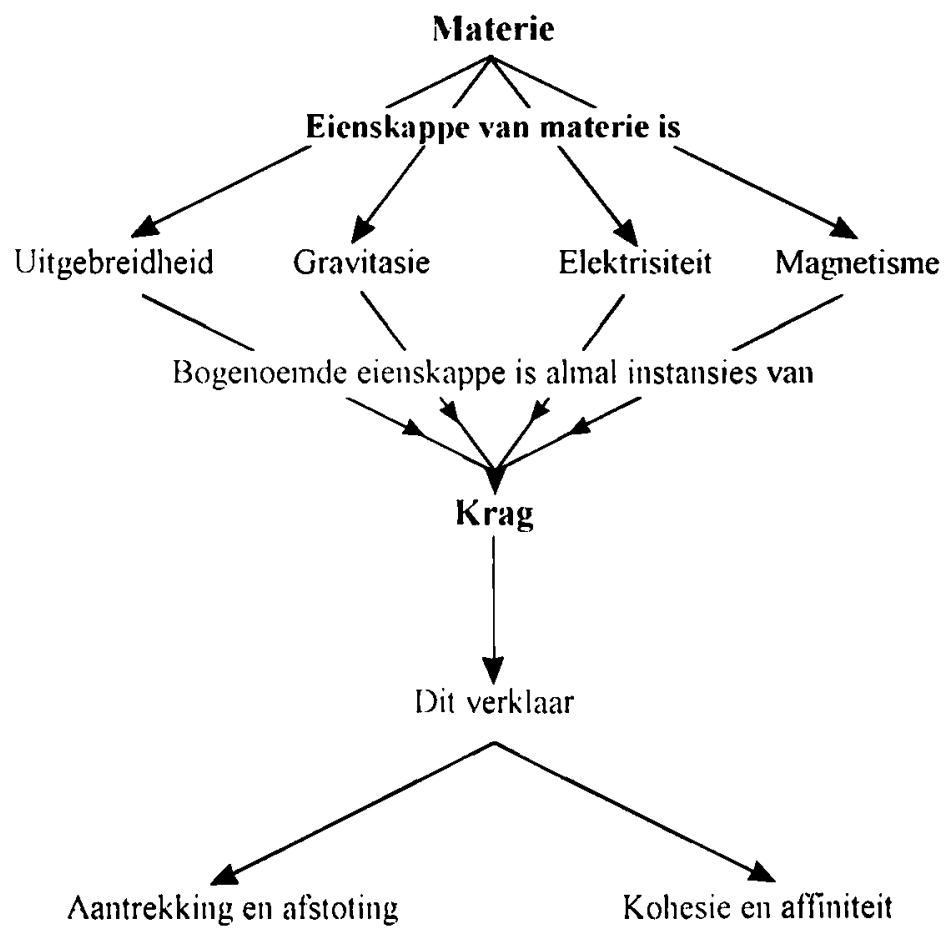

\section{Konseptuele struktuur van kragteskema I}

\footnotetext{
* Materie is 'n entiteit.
} 
* Materie (is soos) kragtevelde.

* Krag is 'n eienskap van die entiteit-materie.

* Uitgebreidheid, gravitasie, elektrisiteit en magnetisme is instansies van hierdie eienskap.

\section{Kragteskema II}

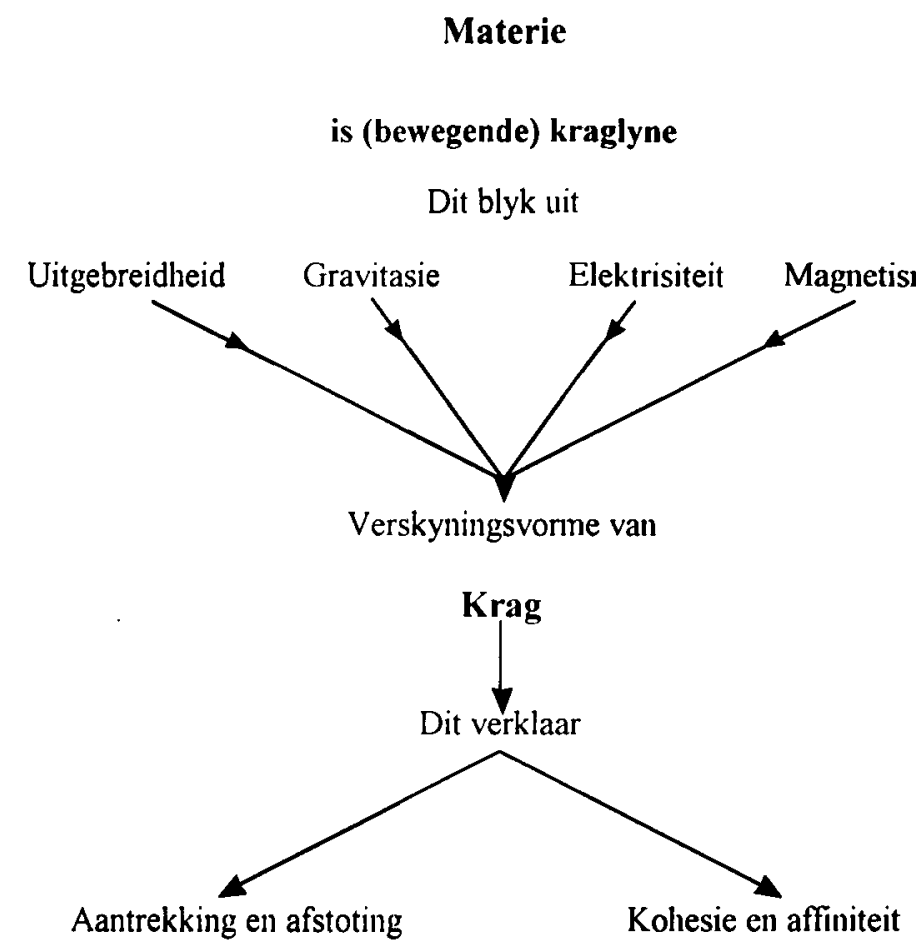

\section{Konseptuele struktuur van kragteskema II}

* Materie is geen entiteit nie.

* Materie is slegs herkenbaar aan sy werkinge/effekte of kragte.

* Materie is niks anders as bewegende kraglyne nie.

* Uitgebreidheid, gravitasie, elektrisiteit en magnetisme is verskyningsvorme van krag. 
Wat in kragteskema II gebeur is dat daar 'n reifisering van die kragmetafoor plaasvind. 'n Nie-letterlike analogie (materie wat lyk soos bewegende kraglyne) word letterlik opgeneem (materie $=\mathrm{krag}$ ). Hierdie wysiging in visie hang ten nouste saam met die empiriese bevindinge in die laboratorium, maar verteenwoordig ook 'n duidelike alternatiewe benadering van die laboratoriumdata. Die stelling dat sodanige wysiging hom in die betekenis van die kragbegrip voltrek, verklaar nog nie waarom dit gebeur nie. Die Cantor-tese wek die indruk dat die konfessioneel religieuse oortuigings veral hierin ' $n$ deurslaggewende rol gespeel het, maar 'n sterk saak sou daarvoor uitgemaak kon word dat hierdie wysiging in religieuse kontrole-oortuiging hoegenaamd nie saamhang met sy konfessionele geloofsoortuigings nie, maar dat dit waarskynlik veel sterker gevoed sou kon wees deur die tydsgees. Hipoteses van hierdie aard word in die literatuur aangetref.

Hoewel Faraday self geen Duits kon lees nie en die Royal Institution in Engeland, waar hy sy lewe lank gewerk het, haas geen Duitse werke besit het nie, was hy tog indirek blootgestel aan die heersende tydsgees van die Duitse Romantiek. Vernoedelik was hy ook beïnvloed deur die invloed van sy leerneester, Davey, wie se assistent hy was en saam met wie hy ook 'n uitgebreide Europese vakansiereis onderneem het. Davey, op sy beurt, was 'n bewonderaar van die Engelse digter-skrywer, Coleridge, wat sterk beinnloed was deur die Duitse Romantiek en Naturphilosophic (Williams, 1965:69, 1973:17). Daar is sitate uit die Natuurfilosofie van Kant wat feitlik woordeliks in die werk van Faraday teruggevind word (vgl. ook Levere, 1981; Kant, 1786:497). Dat die invloed van Kantiaanse denkbeelde en die tydsgees waarin die Duitse Naturphilosophie so 'n belangrike rol gespeel het, hier nie buite rekening gelaat kan word nie, is duidelik. 'n Meer gebalanseerde lesing van Faraday op hierdie punt sou moet rekening hou met sowel die Cantor-tese met sy beklemtoning van die deurslaggewende invloed van sy konfessionele geloofsoortuigings en die klem op die letterlike lesing van die natuur en die Skrif as met die moontlike invloed van die tydsgees soos verteenwoordig deur die Kantiaanse natuurfilosofie en die Duitse Romantiek. Bowendien sou ' $n$ kognitief-historiese benadering juis sodanige inklusiewe aanpak verg. Die hipotese wat egter hier bespreek word, stel dat daar in Faraday se werk 'n duidelike verskuiwing van religieuse kontrole-oortuigings aan te dui is en dat hierdie kontrole-oortuigings saamhang met die dwangbuis waarin sy epistemologiese aannames hom gedwing het. Die verskuiwing in religieuse kontroleoortuiging is juis merkbaar in die duidelike betekenisverskuiwing wat die kragmetafoor ondergaan het en die oorgang vanaf ' $n$ metaforiese lesing van krag na 'n ander oorspanne letterlike lesing van die kragmetafoor in die natuur. Sodanige hipotese pretendeer nie om te verklaar juis waarom hierdie verandering van religicuse kontrole-oortuigings plaasgevind het nie, maar stel eenvoudigweg dat sodanige wysiginge hom in die denke van Faraday voltrek en dat die wysiging merkbaar is in die wyse waarop die kragmetafoor se betekenisinhoud varieer. 
Michael Faraday en die letterlike lesing van die twee 'boeke' van God

Hiermee word iets anders gestel as die Cantor-tese wat redeneer dat Faraday se konfessionele religieuse oortuigings deur sy metafisiese raamwerk bemiddel word. Hier word betoog dat hierdie twee kragte-skemata ook verteenwoordigend is van verskillende aksente in die metafisiese raamwerke waardeur sy wetenskaplike werk gelei is en dat die uiteenlopende fokuspunte identifiseerbaar is met behulp van die metaforiese hermeneutiek van die kragmetafore en onderliggende analogieë waarvan die metafore die linguale projeksies is.

\subsection{Religieuse kontrole-oortuigings in Faraday se wetenskap}

Laat ons vir 'n oomblik terugkeer na Faraday se argument met betrekking tot die aard van materie. Gerekonstrueer lyk sy argument dan soos volg: daar is uiteindelik niks anders nie as krag in die werklikheid. Faraday konsentreer op een van die eienskappe van materie, naamlik krag, stel dit met behulp van 'n ruimtelike beeld voor waarin die lyn-karakter dinamies en beweeglik verstaan word; merk op dat hierdie verskynsel nie slegs tot materie beperk is nie, maar ook buite die materie (tussen die materiedeeltjies in die ruimte) voorkom, en kom dan tot die gevolgtrekking dat daar so 'n alles deurdringende iets soos kraglyne (lines-offorce) bestaan - die kern van sy veldteorie. Faraday verklaar hierdie eienskap van materie identiek met materie. Die metafoor 'materie is soos bewegende kraglyne of kragtevelde' word nou materie $i s(\Rightarrow) \mathrm{krag}$. Die nie-letterlike analogie of metafoor word op dié wyse getransponeer tot 'n letterlike ooreenkoms. Daar is duidelik 'n oorgang van 'n materialisties-meganistiese visie op die aard van materie na 'n meer dinamistiese een en in hierdie oorgang speel die dinamistiese interpretasie van die kraglyne 'n deurslaggewende rol. In hierdie metafoor word die element van dinamiek van beweging die oorheersende fokus, tree dit op soos 'n kontrole-oortuiging wat die verdere interpretasie van die gedrag van materie rig en stuur, tot so 'n mate dat Faraday bereid is om te stel dat daar ... slegs krag bestaan! Hierdie opvatting is 'n duidelike uitdrukking van sy dieperliggende kontrole-oortuiging oor die aard van materie. Wat egter geensins buite rekening gelaat mag word nie is die invloed van die gangbare styl van religieuse en wetenskaplike taalgebruik wat deel uitmaak van hierdie wetenskaplike, godsdienstige en kulturele milieu. Die empirisme het geëis dat die eksperimentele data letterlik verstaan moes word, die gangbare hermeneutiek van die Skrif was die eis van plain style en plain language en die gangbare sterk onderskeiding tussen letterlike en metaforiese taal het meegebring dat die meerduidigheid van begrippe misken was en dat die gebruiker van die metafoor gemaklik deur sy eie metafoor geviktimiseer kon word. Moontlik sou van Faraday se kragkonsep gestel word dat dit eintlik ' $n$ vorm is van metaforiese hipertrofie (Weltman, 1973) waarin die eise van sy diepste konfessionele religieuse oortuigings en die manifestasie daarvan in sy dinamistiese metafisiese raamwerk 'n stel religieuse wetenskaplike kontrole-oortuigings voorgeskryf het wat nie anders kon as om hom 'n slagoffer van sy eie metafoor te maak nie. 


\section{Bibliografie}

AGASSI, J. 1975. Science in Flux. Boston Studies, vd. XXVIII. Dordrecht : Reidel

BERKSON, William. 1974. Fields of Force: The Development of a World View from Faraday to Einstein. New York: Wiley.

BLACK, Max 1962. Models and Metaphors: Studies in Language and Philosophy. Ithaca Cornell. p. 19-45.

BLACK, Max. 1979. More about Metaphor (In Ortony, Andrew ed. Metaphor and Thought Cambridge : Cambridge University Press. p. 19-43.)

BOTHA, ME. 1986. Bewitching or Confusing Metaphysics. The Demarcation between Science and Metaphysics according to Karl Popper. Koers, 51(4):430-440.

BROOKE, John H. 1991. Science and Religion. Some Historical Perspectives. Cambridge Cambridge University Press

BURTT, E.A. 1954. (rev. ed.) The Metaphysical Foundations of Modern Science. Garden City : Doubleday \& Co

CANTOR, Geoffrey. 1991. Michael Faraday. Sandemanian and Scientist. London : Macmillan.

CANTOR, Geoffrey. 1992. Interpreting Michael Faraday as the Christian Philosopher : The Problem of Metaphysics. Unpublished lecture delivered at the Pascal Centre Conference on "Science and Belief", Pascal Centre, Redeemer College, Ancaster, Ontario, Canada, 11-15 August 1992.

CANTOR, Geoffrey N. 1985. Reading the Book of Nature: The Relation between Faraday's Religion and his Science. (III Gooding, David \& James, Frank, A.J.L. eds. Faraday Rediscovered. Essays on the Life and Work of Michael Faraday, 1791-1867. New York : Stockton Press. p. 69-82.)

COLLINGWOOD, R G. 1940. An Essay on Metaphysics. Oxford : London

FARADAY, Michael. 1816. Commonplace Book. Unpublished manuscript in possession of the Institute of Electrical Engineers, London. England.

FARADAY, M. 1844a. A Speculation Touching Electric Conduction and the Nature of Matter. Experimental Researches in Electricity. Letter to Richard Taylor, Esq., London and Fdimburgh Philosophical Magazine, XXIV:136. (Also published in Hutchins, Robert Maynard (Editor in Chief). 1952. Great Books of the Western World, vol. 45. Chicago: Encyclopaedia Brittanica, Inc, Chicago : William Benton. p. 850-851.)

FARADAY, Michael. 1844b. Matter. Manuscript dated 19 February 1844 in the Library of the Institution of Electrical Engineers, London.

FARADAY, Michael. 1844c. A Speculation Touching Electric Conduction and the Nature of Matter. Experimental Researches in Electricity. January 1844. (In Hutchins, Maynard (ed. in chief). 1952. Great Books of the Western World, vol. 45. Encyclopaedia Brittanica. Chicago : William Benton. p. 255-898.)

FARADAY, Michael. 1852. On the Physical Lines of Magnetic Force. Experimental Researches in Electricity. January 1844. (In Hutchins, Maynard (ed. in chief). Great Books of the Western World, vol. 45. Encyclopaedia Brittanica. Chicago : William Benton. p. 255-898.)

FARADAY, Michael 1858. On the Conservation of Force. Proceedings of the Royal Institution, Feb. 27, 1857, vol ii, p. 352. Experimental Researches in Chemistry and Physics. London: Taylor and Francis.

FARADAY, M. 1859. On Mental Education. Lecture delivered in 1854. Experimental Researches in Chemistry and Physics. Bicentennial edition. London : Taylor and Francis, no 1855 
Michael Faraday en die letterlike lesing van die twee 'boeke' van God

FARADAY, M. 1952. Experimental Researches in Electricity, 1831-1855. (In Hutchins, Robert Maynard ed. 1952. Great Books of the Western World, vol. 45. Published by Encyclopaedia Brittanica. Chicago : William Benton. p. 255-898.)

FUNKESTEIN, Amos. 1986. Theology and the Scientific Imagination. From the Middle Ages to the 17th Century. Princeton : Princeton University Press.

GUERLAC, Henry. 1983. Theological Voluntarism and Biological Analogies in Newton's Physical Thought. Journal of the History of Ideas, 44(2):219 -229.

GOODING, David. 1980. Metaphysic Versus Measurement: The Conversion and Conservation of Force in Faraday's Physics. Annals of Science, 37:1-29.

GOODING, David 1982. Empiricism in Practice: Teleology, Economy and Observation in Faraday's Physics. Isis, 73:46-67.

HEIMANN, P.M. 1971. Faraday's Theories of Matter and Electricity. The British Journal for the History of Science, 5(19):235-257.

HESSE, Mary B. 1955. Action at a Distance in Classical Physics. Isis, 46 (4). No. 146, 337 353, Dec.

HESSE, Mary B. 1961. Forces and Fields. The Concept of Action at a Distance in the History of Physics. London. Thomas Nelson and Sons.

HESSE, M.B. 1966. Models and Analogies in Science. Notre Dame : University of Notre Dame Press.

JAMMER, Max 1957. Concepts of Force. A Study in the Foundations of Dynamics. New York : Harper Brothers.

KANT, I. 1786. Philosophy of Material Nature. Translated by Ellington, James, 1985 Indianapolis : Hacket Publishing Co

LEVERE, T.H. 1968. Faraday, Matter and Natural Theology - Reflections on an Unpublished Manuscript. British Journal for the History of Science, 4:95-107.

LEVERE, Trevor H. 1971. Affinity and Matter. Elements of Chemical Philosophy 18001865. Oxford: Clarendon Press.

LEVERE, T.H. 1981. Poetry Realized in Nature. Samuel Taylor Coleridge and Early Nineteenth Century Science. Cambridge : Cambridge University Press

NERSESSIAN, Nancy J. 1984a. Science and Philosophy. Faraday to Einstein: Constructing Meaning in Scientific Theories. Dordrecht : Marthinus Nijhoff Publishers

NERSESSIAN, Nancy J 1984b. Aether/or : The Creation of Scientific Concepts. Sindies in the History and Philosophy of Science, 15(3):175-212.

NERSESSIAN, Nancy J 1987. A Cognitive-Historical Approach to Meaning in Scientific Theories. (In Nersessian, Nancy J. ed. The Process of Science. Contemporary Philosophical Approaches to Understanding Scientific Practice. Dordrecht : Marthinus Nijhoff. p. 161-177.)

NERSESSIAN, Nancy J. 1991a. The Cognitive Sciences and the History of Science. (In Critical Problems and Research Frontiers in History of Science and History of Technology, 30 October - 3 November 1991. Madison, Wisconson. p. 92-115.)

NERSESSIAN, Nancy J. 199lb. Discussion: The Method to "Meaning" : A Reply to Leplin Philosophy of Science, 58(4):678-686, Dec.

NERSESSIAN, Nancy J. 1992. How do Scientists Think? Capturing the Dynamics of Conceptual Change in Science. ( $I n$ Giere, R. ed. Minnesota Studies in the Philosophy of Science. Cognitive Models of Science, vol. XV. Minneapolis : University of Minnesota Press. p. 3-44.)

PAPIN, Liliane. 1992. This is not a Universe: Metaphor, Language and Representation Publications of the Modern Language Association of America, 107 (5): 1253-1265, Oct. 
RUDWICK, Martin. 1981. Senses of the Natural World and Senses of God: Another Look at the Historical Relation of Science and Religion. ( $I n$ Peacocke, A.R. ed. The Sciences and Theology in the Twentieth Century. Notre Dame : University of Notre Dame Press. p. 241-261.)

SPENCER, J. Brookes. 1967/68. Boscovich's Theory and Its Relation to Faraday's Researches: An Analytic Approach. (In Truesdell, C. ed. Archive for History of Exact Sciences, vol. 4. Berlin : Springer-verlag. p. 184-202.)

TORRANCE, T.F. 1980. Ultimate Beliefs and the Scientific Revolution. Cross Currents: 129-149, Summer.

TORRANCE, T.F. 1984. Christian Faith and Physical Science in the Thought of James Clerk Maxwell. (In Torrance, T.F. Transformation and Convergence in the Frame of Knowledge. Grand Rapids : Eerdmans.)

TWENEY, Ryan D. 1989a. Fields of Enterprise: On Michael Faraday's Thought. (In Wallace, Doris B. \& Gruber, Howard E. Creative People at Work. Twelve Cognitive Case Studies. New York : Oxford University Press. p. 91-106.)

TWENEY, Ryan D. 1989b. A Framework for the Cognitive Psychology of Science. (In Gholson, Barry, Shadish, William R. (jr.), Neimeyer, Robert A., Houts, Arthur C. Psychology of Science. Contributions to Metascience. Cambridge : Cambridge University Press. p. 342-366.)

WELTMAN, John J. 1973. Systems Theory in International Relations. A Study in Metaphoric Hypertrophy. Lexington: Heath and $\mathrm{Co}$.

WILLIAMS, L. Pearce. 1965. Michael Faraday. London : Chapman and Hall.

WILLIAMS, L. Pearce. 1973. Kant, Naturphilosophie and Scientific Method. (In Giere, Ronald N. \& Westfall, Richard S. eds. Foundations of Scientific Method. Bloomington : Indiana University Press. p. 3-22.)

WOLTERSTORFF, Nicholas. 1984. Reason within the Bounds of Religion. Grand Rapids: Eerdmans 
